\title{
Implications of Cannabis and Cannabinoid Use in COVID-19: Scoping Review
}

\author{
Implicações do uso da Cannabis e canabinoides na COVID-19: revisão de escopo \\ Implicaciones del uso de Cannabis y cannabinoides en el COVID-19: revisión de alcance
}

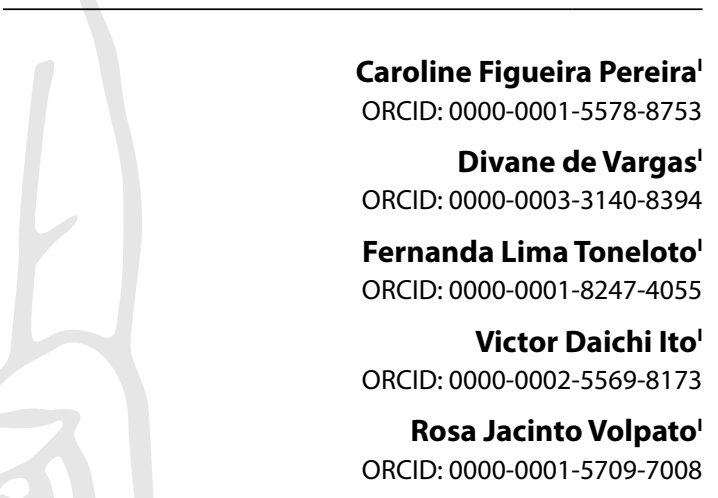

'Universidade de São Paulo. São Paulo, São Paulo, Brazil.

How to cite this article:

Pereira CF, Vargas D, Toneloto FL, Ito VD, Volpato RJ. Implications of Cannabis and Cannabinoid Use in COVID-19: Scoping Review. Rev Bras Enferm. 2022;75(Suppl 1):e20201374. https://doi.org/10.1590/0034-7167-2020-1374

Corresponding author:

Caroline Figueira Pereira

E-mail: pereiracf@usp.br

EDITOR IN CHIEF: Dulce Barbosa ASSOCIATE EDITOR: Rafael Silva

Submission: 01-14-2021

Approval: 09-01-2021

\begin{abstract}
Objective: to identify and synthesize studies on the effects of cannabis use and its relation with SARS-CoV-2, as well as the therapeutic possibilities of using cannabinoids in the prevention and treatment of COVID-19. Methods: scoping review, in the BVS, PubMed, SCIELO, CINAHL, SCOPUS, Web of Science, MedNar, CAPES and ProQuest databases, with no language restriction and year limitation. Narrative synthesis was performed. Results: cannabis use causes changes in the respiratory and vascular system, it reduces the production of cytokines, which affects the users'immune system, increasing the susceptibility to infection and progression of COVID-19. However, studies have suggested the use of cannabinoids in the prophylaxis and treatment of COVID-19, due to their anti-inflammatory effect. Conclusions: the use of inhaled cannabis increases the progression and severity of the infection. On the other hand, the benefits of cannabinoids seem promising to modulate the immune system, but it needs further studies. Descriptors: Marijuana Use; Cannabis; Coronavirus Infections; Mental Health; Nursing.
\end{abstract}

\section{RESUMO}

Objetivo: identificar e sintetizar os estudos sobre os efeitos do uso da cannabis e sua relação com o SARS-CoV-2, bem como as possibilidades terapêuticas da utilização de canabinoides na prevenção e no tratamento da COVID-19. Métodos: revisão de escopo, sem limitação de linguagem e ano, nas bases BVS, PubMed, SCIELO, CINAHL, SCOPUS, Web of Science, MedNar, CAPES e ProQuest. Foi realizada síntese narrativa. Resultados: o consumo de cannabis provoca alterações no sistema respiratório e vascular; reduz a produção de citocinas, o que afeta o sistema imunológico dos usuários, aumentando a susceptibilidade à infecção e a progressão da COVID-19. No entanto, estudos sugeriram o uso de canabinoides na profilaxia e no tratamento da COVID-19, devido ao seu efeito anti-inflamatório. Conclusões: o uso de cannabis inalada aumenta a progressão e a severidade da infecção. Por outro lado, os benefícios dos canabinoides parecem promissores para modular o sistema imunológico, mas necessita de mais estudos. Descritores: Uso da Maconha; Cannabis; Infecções por Coronavírus; Saúde Mental; Enfermagem.

\section{RESUMEN}

Objetivo: identificar y sintetizar los estudios sobre los efectos del uso de cannabis y su relación con el SARS-CoV-2, así como las posibilidades terapéuticas de los cannabinoides para la prevención y el tratamiento del COVID-19. Métodos: revisión de alcance, sin límite de lenguaje y año, planteada en las bases BVS, PubMed, SCIELO, CINAHL, SCOPUS, Web of Science, MedNar, CAPES y ProQuest y desarrollada como síntesis narrativa. Resultados: el consumo de cannabis provoca alteraciones en los sistemas respiratorio y cardiovascular; reduce la producción de citosinas, lo que afecta el sistema inmunológico de los usuarios, aumentando la susceptibilidad a la infección y a la progresión del COVID-19. Sin embargo, algunos estudios sugieren el uso de cannabinoides en la profilaxis y en el tratamiento del COVID-19, debido a su efecto antiinflamatorio. Conclusiones: el uso de cannabis inhalado aumenta la progresión y la gravedad de la infección. Por otra parte, los beneficios de los cannabinoides parecen prometedores para modular el sistema inmunitario, aunque se necesitan más estudios sobre el tema.

Descriptores: Uso de la Marihuana; Cannabis; Infecciones por Coronavirus; Salud Mental; Enfermería. 


\section{INTRODUCTION}

In 2019, the world was surprised by the first contemporary pandemic, COVID-19 (Coronavirus Disease 2019), caused by SARS-CoV-2 (Severe Acute Respiratory Syndrome Coronavirus 2), which spread rapidly, causing death of more than 1900000 people ${ }^{(1)}$. SARS-CoV-2 is part of the Coronaviridae family, which gets its name due to the appearance of a crown when viewed under electron microscopy ${ }^{(2)}$. This coronavirus is responsible for causing respiratory syndrome and effects on other systems, such as the cardiac, renal ${ }^{(3)}$ and central nervous system ${ }^{(4)}$. Coronaviruses are known to cause Severe Acute Respiratory Syndromes (SARS) in humans, such as SARS-CoV (2002), in China, and MERS-CoV (Middle East Respiratory Syndrome) (2012), in Saudi Arabia ${ }^{(5)}$.

The disease caused by SARS-CoV-2 quickly reached pandemic status, reported by the World Health Organization (WHO) on March 11, 2020 $0^{(6)}$. In this context, a worrying factor is that about $25 \%$ of individuals present the infection asymptomatically ${ }^{(7)}$, which further contributes to the rapid spread of the disease due to the lack of isolation necessary to contain the transmission ${ }^{(8)}$, especially because these cases of asymptomatic infection are more common among young people, a population that least adheres to isolation measures ${ }^{(9)}$. On the other hand, the possibility of aggravation of the infection was verified in individuals considered more susceptible and prone to complications, including the older adults and people with clinical and chronic comorbidities (pulmonary, cardiovascular, cerebrovascular and diabetes) ${ }^{(10)}$.

The use of inhaled Psychoactive Substances (PS) can also favor the susceptibility of the organism of these individuals. Marijuana (Cannabis sativa) is the most consumed illicit PS in the world, since its use has been growing in recent years ${ }^{(11)}$. One of the explanations for the increased use is the levels of THC in plants, which increased from $2 \%$ in the 1990 s to around $28 \%$ nowadays ${ }^{(12)}$. In Brazil, the prevalence of users aged 12 to 65 years old is $3.1 \%$ among people living in Brazilian capitals ${ }^{(13)}$.

The use of marijuana causes repercussions on the respiratory system, such as dyspnea, cough and sputum production ${ }^{(14)}$. These events, associated with the respiratory and pulmonary effects resulting from SARS-CoV-2 infection, provide a higher risk of complications of the clinical picture ${ }^{(15-16)}$. In addition, the shared use of marijuana cigarettes is also a worrying factor, due to the greater possibility of contagion ${ }^{(17)}$. Regarding the use of cannabis and its components for therapeutic purposes, information is still controversial as to its effectiveness. However, authors ${ }^{(18-19)}$ raised the hypothesis that marijuana users demonstrated a systemic reduction in the production of cytokines, speculating that cannabidiol (CBD) as a potential inhibitor of the rapid elevation of cytokines during SARS-CoV-2 infection ${ }^{(20-21)}$. Given the context of the pandemic, studies that report adverse effects of marijuana and studies that report the therapeutic effect of CBD, and considering the lack of reviews that group these two views, a review that summarizes the main findings is important.

\section{OBJECTIVE}

To identify and synthesize studies on the effects of cannabis use and its relationship with SARS-CoV-2, as well as the therapeutic possibilities of using cannabinoids in the prevention and treatment of COVID-19.

\section{METHODS}

This study was designed as a scoping review ${ }^{(22)}$ which aims to map the main concepts that support a given area of knowledge; to examine the extent, scope and nature of the investigation, summarize and disseminate research data, and identify gaps in existing research. In addition to the items for systematic reviews and meta-analyses (PRISMA) ${ }^{(23)}$, the specific PRISMA extension for scope reviews (PRISMA-SCR) was also followed, which is ideal for thoroughly describing the decision process of research, considering the method used ${ }^{(24)}$.

The PCC strategy (acronym for P: Population = cannabis users; C: Concept $=$ effects of cannabis; and C: Context $=$ COVID-19) was used to elaborate the guiding question of the study: "What are the knowledge available in the literature on the relationship between the effects of cannabis use and COVID-19?".

\section{Search strategy}

The search strategy was conducted in three stages. The first stage of the research was carried out in PubMed and the BVS (including the BDENF, LILACS, MEDLINE, PAHO-IRIS, WHOLIS and MEDCARIB databases) to analyze the words in the title and abstract of the studies in order to increase the sensitivity of the search strategy, using the following keywords: "Cannabis Smoking", "SARS Virus", "COVID-19". In the second stage, the studies were identified through a search strategy adapted to each electronic database: BVS, SCIELO, PubMed, CINAHL, SCOPUS and Web of Science), with the objective of identifying studies on the subject; and gray literature in the MedNar, CAPES and ProQuest theses and dissertations catalog with the objective of identifying guidelines, manuals, dissertations and theses. A search strategy was developed with the following terms in PubMed, adapted for the other databases: (Cannabis OR "Marijuana Smoking" OR "Marijuana Abuse" OR "Marijuana Use") AND ("COVID19" OR "Corona Virus Disease 2019" OR Coronavirus OR "SARS Virus").

In the third stage, a search was carried out in the references of the selected articles to find studies that were not collected by the search strategy. After collecting all references, duplicate studies were excluded using Mendeley ${ }^{\circledR}$ software. Searches in electronic information sources were carried out from July 2, 2020 to January 5, 2021.

\section{Eligibility criteria}

The inclusion criteria were quasi-experimental studies, randomized clinical trials, cohort, case-control, cross-sectional, letters to the editor or opinion, qualitative studies, review, guidelines, manuals, dissertations and theses that addressed the effects of the use of cannabis and its relationship with COVID-19, its use as a means of preventing infection, and the use of cannabinoids in cases of infection. There was no restriction of language or year of publication.

The instrument "The System for the Unified Management, Assessment and Review of Information" (SUMARI) ${ }^{(25)}$ was used 
for the methodological evaluation of the articles included in the study by two independent evaluators.

\section{Study selection}

The selection of studies was carried out in two phases by the authors of this article. Initially, the titles and abstracts were independently examined in order to verify whether the studies addressed the study's guiding question and met the established inclusion and exclusion criteria. In phase 2 , the same reviewers independently read the full text of all selected articles, excluding studies that did not meet the inclusion criteria. Any disagreement, whether in the first or second phase, was resolved through discussion and agreement between the authors. In case of lack of consensus, a third reviewer was involved for the final decision.

Thus, they were sorted through the following process: title reading; abstract framed in the inclusion and exclusion criteria; exclusion of articles that did not answer the research question and, finally, definitive selection of those eligible for full reading.

\section{Data collection process and results synthesis}

From each article included in the analysis, the authors extracted the following information for descriptive synthesis: location (country), year of publication, study design and outcomes (results).

Subsequently, and independently, the extracted data were verified and changes were made, if necessary. Then, they carried out the quality assessment of the studies using the SUMARI software, through a critical evaluation checklist for experimental studies, expert opinion and review studies by the Joanna Briggs Institute $(\mathrm{JBI})^{(22)}$. Opinion articles and editorials were evaluated using the critical evaluation checklist for opinion studies ${ }^{(26)}$. The cutoff points were established through methodological evaluation checklists for experimental studies, expert opinion and review studies with questions that scored scores from 1 to 10 . Articles that scored between 1 and 4 were classified as of poor methodological quality; articles with scores between 5 and 7 , of moderate quality and those with a score $>7$, of high quality.

\section{RESULTS}

A total of 803 studies were found, among which 16 were duplicated, leaving 787 studies. Of these, 790 were excluded for not meeting the eligibility criteria. Thus, 13 studies were included. Figure 1 shows the flowchart of the selection process of the articles in this research - PRISMA flow chart.

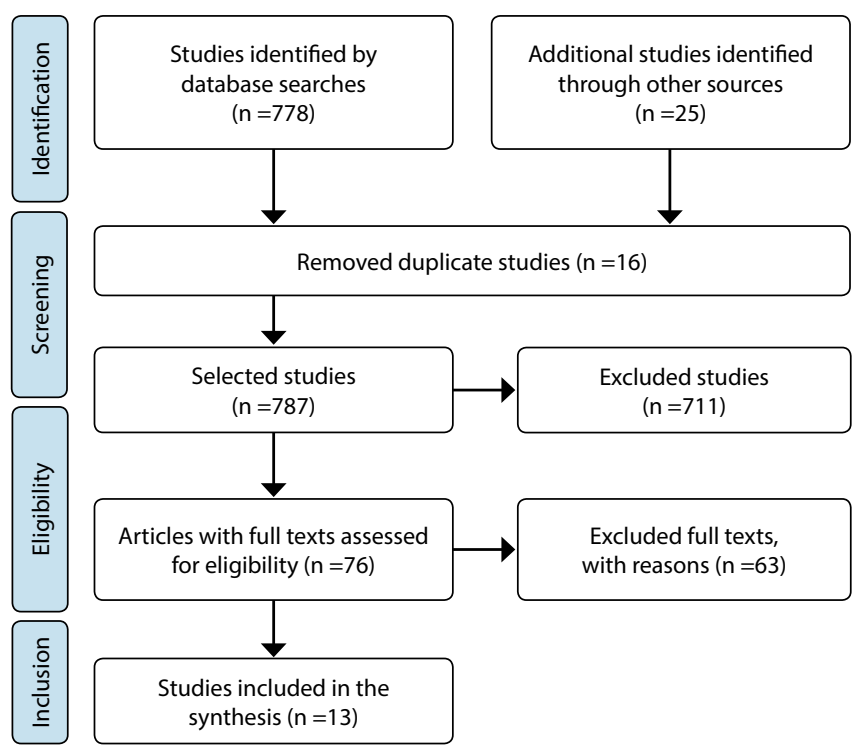

Figure 1 - Flowchart of the study selection process

\section{Characteristics of the studies}

All included studies were written in English, with seven studies conducted in the United States, two in Italy, two in Canada, one in South Africa and one in Iran. Eight studies were opinion, two considered experimental, two review studies, and one quasiexperimental. In Chart 1, the descriptive characteristics of the studies are summarized.

Chart 1 - Characteristics of the included studies, according to title, year of publication, country, design, outcomes and methodological quality, Brazil, 2020 ( $N=13$ )

\begin{tabular}{|c|c|c|c|c|}
\hline Title & $\begin{array}{c}\text { Year/ } \\
\text { Country }\end{array}$ & Design/objective & $\begin{array}{l}\text { Outcomes of studies on the effects of cannabis use and its } \\
\text { relationship with SARS-COV2 and the therapeutic possibilities } \\
\text { of cannabinoids in the prevention and treatment of COVID-19 }\end{array}$ & $\begin{array}{c}\text { Methodological } \\
\text { quality }\end{array}$ \\
\hline $\begin{array}{l}\text { Cannabis in the } \\
\text { Time of Coronavirus } \\
\text { Disease 2019: The } \\
\text { Yin and Yang of the } \\
\text { Endocannabinoid } \\
\text { System in } \\
\text { Immunocompetence }{ }^{(16)}\end{array}$ & $\begin{array}{l}2020 \\
\text { USA }\end{array}$ & $\begin{array}{l}\text { Opinion article } \\
\text { Objective: To } \\
\text { assess whether } \\
\text { Phytocannabinoids can } \\
\text { be useful or harmful to } \\
\text { immune competence in } \\
\text { the context of the current } \\
\text { COVID-19 pandemic. }\end{array}$ & $\begin{array}{l}\text { - The chronic use of inhaled cannabis can increase coughing, sputum } \\
\text { production, wheezing, reduced lung function, and can cause respiratory } \\
\text { illnesses. These changes reduce the effectiveness of the response to } \\
\text { infection, increasing the risk of rapid progression to hypoxia; } \\
\text { - Cannabis users showed systemic reduction in cytokine production; } \\
\text { - The endogenous cannabinoid signaling system (ECS) mediates } \\
\text { several immunosuppressive effects, including inhibition of immune } \\
\text { cell proliferation, migration and antibody production, induction of } \\
\text { apoptosis, and suppression of cytokines; } \\
\text { - CBD has been perceived as a potential treatment for COVID-19 due to } \\
\text { its anti-inflammatory effects. }\end{array}$ & High \\
\hline $\begin{array}{l}\text { Cannabinoids and } \\
\text { the Coronavirus }\end{array}$ & $\begin{array}{l}2020 \\
\text { USA }\end{array}$ & $\begin{array}{l}\text { Opinion article } \\
\text { Objective: To identify } \\
\text { the benefits and risks of } \\
\text { cannabinoids with regard } \\
\text { to Covid-19. }\end{array}$ & $\begin{array}{l}\text { - SARS-CoV-2 triggers excessive production of cytokines, resulting } \\
\text { in hyperinflammation. CBD could possibly be part of the treatment, } \\
\text { associated with non-steroidal anti-inflammatory drugs and other } \\
\text { medications that act on the immune system, with the aim of reducing } \\
\text { the overproduction of these substances. }\end{array}$ & High \\
\hline
\end{tabular}


Chart 1

\begin{tabular}{|c|c|c|c|c|}
\hline Title & $\begin{array}{c}\text { Year/ } \\
\text { Country }\end{array}$ & Design/objective & $\begin{array}{l}\text { Outcomes of studies on the effects of cannabis use and its } \\
\text { relationship with SARS-COV2 and the therapeutic possibilities } \\
\text { of cannabinoids in the prevention and treatment of COVID-19 }\end{array}$ & $\begin{array}{c}\text { Methodological } \\
\text { quality }\end{array}$ \\
\hline $\begin{array}{l}\text { Cannabidiol } \\
\text { Modulates Cytokine } \\
\text { Storm in Acute } \\
\text { Respiratory Distress } \\
\text { Syndrome Induced } \\
\text { by Simulated Viral } \\
\text { Infection Using } \\
\text { Synthetic RNA }\end{array}$ & $\begin{array}{l}2020 \\
\text { USA }\end{array}$ & $\begin{array}{l}\text { Experimental study with } \\
\text { animal model. } \mathrm{N}=15 \text { mice. } \\
\text { Objective: To assess } \\
\text { whether CBD can reduce } \\
\text { cytokine storm and treat } \\
\text { acute respiratory distress } \\
\text { syndrome. }\end{array}$ & $\begin{array}{l}\text {-The treatment with CBD reversed the inflammatory indices and } \\
\text { partially reestablished the body's homeostasis; } \\
\text { - It reduced the expression of interleukin (IL)- } 6 \text { and decreased the } \\
\text { presence of neutrophils in the lung and blood; } \\
\text { - It increased the presence of lymphocytes, reduced the number of } \\
\text { neutrophils and monocytes, as well as the level of pro-inflammatory } \\
\text { cytokines. }\end{array}$ & High \\
\hline $\begin{array}{l}\text { Cerebrovascular } \\
\text { and neurological } \\
\text { dysfunction under } \\
\text { the threat of } \\
\text { COVID-19: Is there } \\
\text { a comorbid role } \\
\text { for smoking and } \\
\text { vaping?(27) }\end{array}$ & $\begin{array}{l}2020 \\
\text { USA }\end{array}$ & $\begin{array}{l}\text { Review article. } \mathrm{N}=9 \\
\text { studies } \\
\text { Objective: } \text { To summarize } \\
\text { the possible role of } \\
\text { smoking and vaporization } \\
\text { in cerebrovascular and } \\
\text { neurological dysfunction } \\
\text { in patients with } \\
\text { COVID-19. }\end{array}$ & $\begin{array}{l}\text { - The use of inhaled cannabis can deteriorate the condition of } \\
\text { patients with COVID-19, due to airway inflammation, being a risk } \\
\text { factor for the development of neurological disorders, due to the } \\
\text { harmful effect on the cerebrovascular system. }\end{array}$ & Moderate \\
\hline $\begin{array}{l}\text { The potential of } \\
\text { Cannabidiol in } \\
\text { the COVID-19 } \\
\text { pandemic } \\
\text { (30) }\end{array}$ & $\begin{array}{l}2020 \\
\text { Italy }\end{array}$ & $\begin{array}{l}\text { Opinion article } \\
\text { Objective: To identify } \\
\text { effective drugs in the new } \\
\text { coronavirus disease } 2019 \\
\text { (COVID - 19). }\end{array}$ & $\begin{array}{l}\text { - Cannabis sativa extracts with a high content of cannabinoid (CB) } \\
\text { are able to reduce the expression of the two main receptors for the } \\
\text { installation of SARS-CoV- } 2 \text { infection: the angiotensin } 2 \text { converting } \\
\text { enzyme and the serine protease } 2 \text { enzymes; } \\
\text { - CBD exerts a wide range of immunomodulatory and anti- } \\
\text { inflammatory effects, smoothing the uncontrolled production of } \\
\text { cytokines in acute lung injury, acting as a regulator of fibroblast/ } \\
\text { myofibroblast activation .and improving lung function in recovered } \\
\text { patients. }\end{array}$ & High \\
\hline $\begin{array}{l}\text { Acute inflammation } \\
\text { and pathogenesis of } \\
\text { SAR-CoV-2 infection: } \\
\text { cannabidiol as a } \\
\text { potential anti- } \\
\text { inflammatory } \\
\text { treatmen }{ }^{\mathrm{t}(28)}\end{array}$ & $\begin{array}{c}2020 \\
\text { Canada }\end{array}$ & $\begin{array}{l}\text { Opinion article } \\
\text { Objective: To assess } \\
\text { Cannabidiol's potential } \\
\text { to attenuate excessive } \\
\text { inflammation. }\end{array}$ & $\begin{array}{l}\text { - CBs can suppress immune and inflammatory activation by reducing } \\
\text { the production of cytokines, suggesting potential to modulate } \\
\text { excessive inflammation; } \\
\text { - Cannabis use was associated with a reduction in pro-inflammatory } \\
\text { monocytes, a reduction in CD4 and CD8 T lymphocyte cells, in } \\
\text { addition to tumor necrosis factor alpha (TNF-a), IL-10 and IL- } \\
\text { producing antigen-presenting cells } 12, \text { compared to non-cannabis } \\
\text { users. }\end{array}$ & Moderate \\
\hline $\begin{array}{l}\text { Cannabinoid } \\
\text { receptor type 2: a } \\
\text { possible target in } \\
\text { SARS-CoV-2 (CoV-19) } \\
\text { infection }{ }^{?(34)}\end{array}$ & $\begin{array}{l}2020 \\
\text { Italy }\end{array}$ & $\begin{array}{l}\text { Opinion article } \\
\text { Objective: To assess } \\
\text { whether the CB2 receptor } \\
\text { can be a therapeutic } \\
\text { target in the COVID-19 } \\
\text { pandemic emergency. }\end{array}$ & $\begin{array}{l}\text { - Endocannabinoid CB2 receptor stimulation is known to limit the } \\
\text { release of pro-inflammatory cytokines, change the macrophage } \\
\text { phenotype to the } M 2 \text { anti-inflammatory type, and enhance the } \\
\text { immune modulating properties of cells; } \\
\text { - For these reasons, it is hypothesized that the CB2 receptor may be } \\
\text { a therapeutic target in cases of COVID-19 infection, playing a role in } \\
\text { preventing and/or influencing the development and severity of the } \\
\text { disease. }\end{array}$ & Moderate \\
\hline $\begin{array}{l}\text { Opioids/ } \\
\text { cannabinoids as } \\
\text { potential therapeutic } \\
\text { approach in } \\
\text { COVID-19 patients }\end{array}$ & $\begin{array}{l}2020 \\
\text { Iran }\end{array}$ & $\begin{array}{l}\text { Opinion article } \\
\text { Objective: To assess } \\
\text { the use of opioids/ } \\
\text { cannabinoids in the } \\
\text { context of COVID-19. }\end{array}$ & $\begin{array}{l}\text { - CB2 stimulation could control the inflammatory cascade caused } \\
\text { by SARS-CoV-2 infection, considering its ability to reduce the } \\
\text { exacerbated production of pro-inflammatory cytokines; } \\
\text { - Considering this scenario, its use can be very beneficial in the } \\
\text { exacerbated containment of the inflammatory response in patients } \\
\text { with COVID-19. }\end{array}$ & High \\
\hline $\begin{array}{l}\text { Cannabis for } \\
\text { COVID-19: can } \\
\text { cannabinoids } \\
\text { quell the cytokine } \\
\text { storm?(31) }\end{array}$ & $\begin{array}{l}2020 \\
\text { USA }\end{array}$ & $\begin{array}{l}\text { Opinion article } \\
\text { Objective: To assess } \\
\text { the potential of the } \\
\text { pharmacological } \\
\text { immunomodulatory } \\
\text { effects of cannabinoids } \\
\text { that are constituents of } \\
\text { the cannabis plant. }\end{array}$ & $\begin{array}{l}\text { - CBs are effective in suppressing the immune system, having } \\
\text { immunoregulatory and anti-inflammatory properties, resulting from } \\
\text { the activation of CB1 and CB2 receptors; } \\
\text { - ECS mediates immunosuppression through cytokine suppression; } \\
\text { inhibition of immune cell proliferation, migration and antibody } \\
\text { production, allowing control of viral pathogenesis; } \\
\text { - The phytocannabinoids, tetrahydrocannabinol (THC) and CBD, have } \\
\text { been shown to reduce the exacerbated production of inflammatory } \\
\text { cytokines through their immunoregulatory properties. }\end{array}$ & High \\
\hline $\begin{array}{l}\text { Letter to the Editor: } \\
\text { Possible Drug-Drug } \\
\text { Interactions Between } \\
\text { Cannabinoids and } \\
\text { Candidate COVID-19 } \\
\text { Drugs }^{(36)}\end{array}$ & $\begin{array}{l}2020 \\
\text { USA }\end{array}$ & $\begin{array}{l}\text { Opinion article } \\
\text { Objective: Early } \\
\text { identification of possible } \\
\text { interactions between } \\
\text { cannabinoids and drugs } \\
\text { that can be used to treat } \\
\text { COVID-19. }\end{array}$ & $\begin{array}{l}\text { - The interaction of some CBs with certain medications can be } \\
\text { extremely serious, potentially causing hepatocellular damage and } \\
\text { sedation; } \\
\text { - The immunosuppressive effects associated with CBD can trigger a } \\
\text { primary and/or secondary infectious condition, resulting in a worse } \\
\text { prognosis in patients with COVID-19; } \\
\text { - A recent in vitro study showed that CBD can antagonize some } \\
\text { effects of dexamethasone, replacing its anti-inflammatory potential, } \\
\text { when used concomitantly. }\end{array}$ & High \\
\hline
\end{tabular}




\begin{tabular}{|c|c|c|c|c|}
\hline Title & $\begin{array}{c}\text { Year/ } \\
\text { Country }\end{array}$ & Design/objective & $\begin{array}{l}\text { Outcomes of studies on the effects of cannabis use and its } \\
\text { relationship with SARS-COV2 and the therapeutic possibilities } \\
\text { of cannabinoids in the prevention and treatment of COVID-19 }\end{array}$ & $\begin{array}{c}\text { Methodological } \\
\text { quality }\end{array}$ \\
\hline $\begin{array}{l}\text { Genetic Liability } \\
\text { to Cannabis } \\
\text { Use Disorder } \\
\text { and COVID-19 } \\
\text { Hospitalization(29) }^{(29)}\end{array}$ & $\begin{array}{l}2020 \\
\text { USA }\end{array}$ & $\begin{array}{l}\text { Quasi-experimental. } \\
\text { Cannabis Use Disorder } \\
\text { ( } \mathrm{N} \text { case }=14080, \mathrm{~N} \\
\text { control }=343726 \text { ) } \\
\text { and hospitalization for } \\
\text { COVID-19 ( } \mathrm{N} \text { case }=6492, \\
\mathrm{~N} \text { population control = } 1 \\
012809 \text { ). } \\
\text { Objective: To identify } \\
\text { whether genomic } \\
\text { responsibility for cannabis } \\
\text { use disorder can contribute } \\
\text { to severe presentation of } \\
\text { COVID-19. }\end{array}$ & $\begin{array}{l}\text { - The heavy and/or problematic use of cannabis associated with the } \\
\text { genetic factor for cannabis use disorder may increase the severity of } \\
\text { COVID-19 due to respiratory complications; } \\
\text { - The formulation of strategies to reduce heavy cannabis use is } \\
\text { recommended to mitigate risks in relation to COVID-19. }\end{array}$ & High \\
\hline $\begin{array}{l}\text { In search of } \\
\text { preventive strategies: } \\
\text { novel high-CBD } \\
\text { Cannabis sativa } \\
\text { extracts modulate } \\
\text { ACE2 expression in } \\
\text { COVID-19 gateway } \\
\text { tissues }^{(32)}\end{array}$ & $\begin{array}{c}2020 \\
\text { Canada }\end{array}$ & $\begin{array}{l}\text { Experimental study. } \mathrm{N}=23 \\
\text { Objective: To assess } \\
\text { whether C. sativa extracts } \\
\text { with high CBD content } \\
\text { can be used to down- } \\
\text { regulate ACE2 expression } \\
\text { in COVID-19 target tissues. }\end{array}$ & $\begin{array}{l}\text { - By using artificial 3D human tissue models, it was observed that } \\
\text { Cannabis sativa extracts with high content of CBD can decrease the } \\
\text { expression of angiotensin-converting enzyme (ACE2) in coronavirus } \\
\text { target tissues, suggesting the importance of these extracts in } \\
\text { prevention of COVID-19; } \\
\text { - These results cannot be extrapolated to the effects of cannabis } \\
\text { smoking. }\end{array}$ & High \\
\hline $\begin{array}{l}\text { Coronavirus } \\
\text { Disease-2019 } \\
\text { Treatment } \\
\text { Strategies Targeting } \\
\text { Interleukin-6 } \\
\text { Signaling and Herbal } \\
\text { Medicine }^{(33)}\end{array}$ & $\begin{array}{l}2021 \\
\text { South } \\
\text { Africa }\end{array}$ & $\begin{array}{l}\text { Review article. } \mathrm{N}=15 \\
\text { studies } \\
\text { Objective: To map } \\
\text { therapeutic strategies } \\
\text { by blocking the cytokine } \\
\text { storm }\end{array}$ & $\begin{array}{l}\text { - The search for potential strategies to target IL- } 6 \text { signaling in the } \\
\text { treatment of COVID-19 patients, such as: tocilizumab (decreases } \\
\text { cytokine release), IL- } 6 \text { signaling inhibitors (pacritinib, ruxolitinib and } \\
\text { tofacitinib), bone marrow-derived exosomes, and dexamethasone; } \\
\text { - Another plausible strategy is the use of natural compounds with the } \\
\text { ability to inhibit virus entry into host cells; } \\
\text { - Among them is Cannabis sativa, which is a plant known for containing } \\
\text { anti-inflammatory compounds such as CB, CBD and terpenes. }\end{array}$ & Moderate \\
\hline
\end{tabular}

Studies ${ }^{(16,27-28)}$ point to evidence that cannabis in the inhaled form causes important changes in the respiratory and in the vascular system, causing damage to the individuals'brain structure, reduction in the concentration of TCD4, CD8 and cytokines, which may result in inefficient activation of users'immune systems. Furthermore, the presence of a genetic risk factor for cannabis use disorder is correlated with COVID-19 and an increase in hospitalization cases ${ }^{(29)}$.

On the other hand, researches ${ }^{(16,20-21,30-35)}$ addressed the possibility of using exogenous $\mathrm{CB}$, especially $\mathrm{CBD}$ and $\mathrm{THC}$, in the prophylaxis and treatment of COVID-19 through the suppression of immune activation, with an anti-inflammatory and reduced expression of ACE2 in coronavirus target tissues. A study ${ }^{(36)}$ highlights the risk of drug interactions of THC and/or CBD with anti-inflammatory drugs used in the treatment of infection caused by SARS-CoV-2.

\section{DISCUSSION}

This study was designed to analyze the literature on the effects of cannabis and its relationship with SARS-CoV-2, in addition to discussing the possibility of using exogenous $C B$ for therapeutic intervention in cases of infection by this virus, as well as in preventing the disease. During the pandemic and the lockdown period, changes were observed in the population's routine, directly reflected in the mental health of individuals ${ }^{(37)}$, affected by different degrees of mental suffering. Specialists warn of the possibility of worsening PS use patterns, as this is one of the strategies pointed out for coping with mental suffering ${ }^{(38)}$. A study ${ }^{(39)}$ carried out in Canada highlighted that from May to June 2020 , the use of marijuana was maintained, but when compared to the period before the pandemic, these rates increased. On the other hand, the literature indicates that in Belgium and the United States of America there was no change in the use of cannabis during the pandemic ${ }^{(40-41)}$.

Regardless of this controversy, the use of cannabis in the inhaled form causes concern when in the context of COVID-19. This PS has harmful consequences for lung health, reducing the effectiveness of the response to infection through airway inflammation, and may increase the risk of rapid progression to hypoxia in cases of SARS-CoV-2 infection ${ }^{(15,27)}$. Other alterations are chronic inflammation of the lungs and impairment of the vascular system, due to the large increase in THC levels ${ }^{(42)}$. It is noteworthy that SARS-CoV-2 provokes massive recruitment of macrophages and monocytes, but that, in some cases, this immune response is dysfunctional and directly affects the respiratory system, which can be exacerbated in a systemic way ${ }^{(43)}$.

The chronic use of cannabis is related to cardiac events (atrial fibrillation and acute coronary syndromes) and effects on cerebral blood vessels ${ }^{(44-45)}$. This evidence may be important for more detailed observations in the treatment of these individuals, as SARS-CoV-2 directly affects the myocardium, in addition to causing venous thromboembolism and arterial thrombosis in the neurovascular system ${ }^{(46)}$. Other important factors highlighted were that the $\mathrm{CB}$ present in cannabis can cause an important drug interaction, pointing to the need for adequate investigation regarding its use during a suspicion of contamination by SARS-CoV- $2^{(36)}$. In addition, attention to the genetic factor that predisposes to cannabis use disorder is necessary, being listed as a risk of increased hospitalization in cases of COVID-19 ${ }^{(29)}$. In 
addition to the systemic changes caused by cannabis use, individuals who use it as a medicinal resource may have an increased risk of contracting the infection due to chronic health conditions, such as cancer and heart disease ${ }^{(29,47)}$.

In summary, the act of smoking cannabis can be extremely harmful to individuals infected with the coronavirus, contributing to a negative outcome of the disease. Thus, it is necessary to develop longitudinal studies to assess how cannabis users, in the inhaled form, react to SARS-CoV-2 infection. The extremely important role of guidance, prevention and harm reduction performed by nursing in primary health care services and specialized services is highlighted. Through these approaches, the objective is to alert the population to consequences in relation to the use of inhaled cannabis, since cannabis is the second most used drug worldwide, by about 192 million people ${ }^{(48)}$.

The data presented show the need to carry out tracking of the use and abuse of cannabis among individuals who present symptoms of contamination by SARS-CoV-2, as it is essential to mitigate the effects caused by this virus. Subsequently, it would be possible to trace a contamination profile to establish a prognosis for this population. Thus, the nurse has the potential to carry out screening and brief intervention effectively ${ }^{(49-50)}$, strengthening the role of this professional in mental health care ${ }^{(51)}$, regardless of the health care sector they act. In addition, nurses who work in specialized services in alcohol and other drugs must identify and intervene in risk situations that favor the infection of people by SARS-CoV-2.

Regarding probable therapeutic uses, both THC and CBD have been mentioned in the literature as having an important function of modulating the immune system, acting in the inhibition of inflammatory cytokines and in the stimulation of anti-inflammatory cytokines $^{(52)}$, confirmed by several studies ${ }^{(16,20-21,30-33,35)}$. Despite disagreements about the safety of cannabis and CB use, some regulatory agencies have allowed the use of CB-based drugs for the treatment of epilepsy and multiple sclerosis and for the relief of symptoms of chemotherapy, allowing new perspectives for future applications ${ }^{(51,53)}$.

ECS is known to mediate several immunosuppressive effects, including inhibition of immune cell proliferation, migration and antibody production, and induction of apoptosis and suppression of cytokines (via down-regulation of immunoregulatory genes). This suggests the possibility of using exogenous CB in cases of infection by SARS-CoV-2 $2^{(16,28,30-31,33)}$, aiming to reduce the excess of cytokines ${ }^{(20)}$. These findings are in line with the treatment guidelines proposed for COVID-19, with the use of agents that perform immunomodulation to reduce excess cytokines in the inflammatory process ${ }^{(46)}$.

The use of CBD may also be a promising agent for patients recovering from COVID-19 due to improved pulmonary function ${ }^{(30)}$. Furthermore, the therapeutic potential in the treatment of cardiovascular pathologies has been considered in the literature ${ }^{(51)}$. Another resource would be the prevention strategy against the entry of SARS-CoV-2, through the use of mouthwashes containing Cannabis sativa with a high content of $\mathrm{CBD}^{(30)}$, which would act by modulating the expression of ACE2 expressed in the oral cavity $^{(32)}$. Studies ${ }^{(31,33)}$ reinforce the need for further research with a view to confirming the beneficial findings in relation to cannabis, $\mathrm{CB}$ and other components that have so far been shown to be promising for the treatment of various pathologies, including COVID-19. However, studies ${ }^{(21,35-36)}$ alert to the need for more evidence about the mechanisms of action, drug interaction and use in the treatment of COVID-19.

There was little evidence addressing the use of exogenous $C B$ for therapeutic purposes during and after the individual contracted COVID-19, but with positive indications for the immunomodulatory effect through the activation and inhibition of cytokines ${ }^{(16,20-21,28,30-35)}$. Therefore, it is necessary to develop further research that explores this use, especially in individuals with coronavirus infection. As for the non-therapeutic use of cannabis, among people who contracted COVID-19, studies ${ }^{(16,27,30)}$ point to the health risks in relation to the potential inflammatory triggering of the vascular and respiratory systems, and in relation to the likely danger of the interaction drug with the components of cannabis ${ }^{(36)}$.

Nursing and other health professionals must be aware of this scenario in order to properly guide the population, ensuring understanding the difference between the indiscriminate use of cannabis and the therapeutic use based on scientific evidence. Thus, it avoids misinterpretations and indiscriminate use of this PS as a resource for the prevention of COVID-19, especially among individuals who did not use it.

\section{Limitations of the study}

Some limitations of this study should be considered, such as the lack of evidence regarding the use of cannabis and its substrates in patients who developed COVID-19, pointing out that these factors may have been little observed in robust studies. In addition, there is the methodological design of the studies included in the review, since eight selected studies ${ }^{(16,20,28,30-31,34-36)}$ are opinion articles, which limits the affirmation power of the results in relation to the investigated phenomenon. However, this study type is configured as one of the types of manuscripts recommended for including in a scoping review.

\section{Contributions to the area of Nursing, Health or Public Policy}

This review aims to bring a contribution of knowledge about the use of cannabis, inhaled and therapeutically, in the context of the COVID-19 pandemic. Nurses are the backbone of the health system, seeking to provide care centered on the individual regardless of the working environment. Thus, during the COVID-19 pandemic, these professionals will certainly provide care to cannabis users, using an empathetic, welcoming and always attentive approach to the peculiarities of the association between cannabis use and SARS-CoV-2. In addition, the nurse must be aware of respiratory and cardiovascular symptoms, in addition to tracking the use of PS, especially cannabis, in individuals under their care, in order to provide more adequate and comprehensive care, based on the biopsychosocial care model. Therefore, it will contribute to improve the prognosis arising from the infection caused by this virus, aiming to improve the prognosis for COVID-19. This study contributes to the formulation of new health policies acting as an evidence-based literature. In addition, it highlights the current theme of the pandemic and its implications, reinforcing the perspective of damage to the body of individuals in the use/ 
abuse of cannabis. On the other hand, it shows the promising potential of isolated components (exogenous $\mathrm{CB}$ ) for therapeutic purposes and new treatment possibilities for several pathologies that involve exacerbated activation of the immune system.

We emphasize the need to develop more studies that address and investigate the prognosis of patients with COVID-19 and who use inhaled cannabis, as well as the therapeutic use of exogenous cannabinoids in the prevention and treatment of infection by SARS-CoV-2, for the regulation and adoption of public policy of its use for these purposes to take place.

\section{CONCLUSION}

Individuals who use inhaled cannabis may be more susceptible to infection and progression of SARS-CoV-2, due to the effects resulting from this use, which interfere with various systems of the human body. Furthermore, non-therapeutic use may be a risk factor for the development of neurological disorders in people affected by COVID-19. This highlights the need to carry out interventions aimed at preventing the use and abuse of marijuana, reinforcing the harmful relationship with SARS-CoV-2 infection. In this context, nursing professionals are in a privileged situation, due to the intense contact with the individuals under their care at all levels of health care.

Another important factor is the awareness of health professionals about studies that point to cannabis as a promising immunomodulatory and anti-inflammatory drug, bringing to light the benefits of the active ingredients isolated from the plant, such as CBD and THC, for the treatment of the disease caused by SARS-CoV-2.

\section{REFERENCES}

1. World Health Organization (WHO). Painel do WHO Coronavirus Disease (COVID-19) [Internet]. WHO; 2020[cited 2021 Jan 12]. Available from: https://covid19.who.int/

2. Zhu N, Zhang D, Wang W, Li X, Yang B, Song J, et al. A novel coronavirus from patients with pneumonia in China, 2019. N Engl J Med. 2020;382(8):727-33. https://doi.org/10.1056/NEJMoa2001017

3. Zhou F, Yu T, Du R, Fan G, Liu Y, Liu Z, et al. Clinical course and risk factors for mortality of adult inpatients with COVID-19 in Wuhan, China: a retrospective cohort study. Lancet. 2020;395(10229):1054-62. https://doi.org/10.1016/S0140-6736(20)30566-3

4. Groiss SJ, Balloff C, Elben S, Brandenburger T, Müttel T, Kindgen-Milles D, et al. Prolonged neuropsychological deficits, central nervous system involvement, and brain stem affection after COVID-19-A case series. Front Neurol. 2020;11:574004. https://doi.org/10.3389/fneur.2020.574004

5. Yin Y, Wunderink RG. MERS, SARS and other coronaviruses as causes of pneumonia. Respirology. 2018;23(2):130-137. https://doi. org/10.1111/resp.13196

6. World Health Organization. WHO Director-General's opening remarks at the media briefing on COVID-19-11 March 2020 [Internet]. WHO Director General's speeches. 2020[cited 2020 Sep 12];(Mar):4. Available from: https://www.who.int/director-general/speeches/detail/whodirector-general-s-opening-remarks-at-the-media-briefing-on-covid-19---11-march-2020 .

7. Dennison HCR, Baptiste D. Coronavirus Disease (COVID-19): Implications for Cardiovascular and Socially At-risk Populations. J CardiovasC Nurs. 2020;35(4):318-21. https://doi.org/10.1097/JCN.0000000000000710

8. Wilder-Smith A, Chiew CJ, Lee VJ. Can we contain the COVID-19 outbreak with the same measures as for SARS?. Lancet Infect Dis. 2020;20(5):e102-e107. https://doi.org/10.1016/S1473-3099(20)30129-8

9. Nikolai LA, Meyer CG, Kremsner PG, Velavan TP. Asymptomatic SARS Coronavirus 2 infection: Invisible yet invincible. Int J Infect Dis. 2020;100:112-6. https://doi.org/10.1016/j.jiji.2020.08.076

10. Dunlop A, Lokuge B, Masters $D$, Sequeira $M$, Saul $P$, Dunlop $G$, et al. Challenges in maintaining treatment services for people who use drugs during the COVID-19 pandemic. Harm Reduct J. 2020;17(1):26. https://doi.org/10.1186/s12954-020-00370-7

11. World Drug Report 2018. Executive summary - Conclusions and Policy Implications [Internet]. Vol. 1, United Nations publication, Sales No. E.18.XI.9; 2018 [cited 2020 Nov 28]. Available from: https://www.unodc.org/wdr2018/prelaunch/WDR18_Booklet_1_EXSUM.pdf

12. Stuyt E. The Problem with the Current High Potency THC Marijuana from the Perspective of an Addiction Psychiatrist. Mo Med [Internet]. 2018 [cited 2020 Nov 28];115(6):482-486. Available from: http://www.ncbi.nlm.nih.gov/pubmed/30643324

13. Bastos FIPM, Vasconcellos MTL, De Boni RB, et al. 3rd National Survey on Drug Use by the Brazilian Population [Internet]. Rio de Janeiro: FIOCRUZ/ICICT, 2017[cited 2020 Nov 27]. 528 p. Available from: https://www.arca.fiocruz.br/handle/icict/34614

14. Gracie K, Hancox RJ. Cannabis use disorder and the lungs. Addiction. 2020:add.15075. https://doi.org/10.1111/add.15075

15. El Biali M, Broers B, Besson M, Demeules J. Cannabinoids and COVID-19. Med Cannabis Cannabinoids. 2020:1-5. https://doi. org/10.1159/000510799

16. Sexton M. Cannabis in the Time of Coronavirus Disease 2019: The Yin and Yang of the Endocannabinoid System in Immunocompetence. J Altern Complement Med. 2020;26(6):444-8. https://doi.org/10.1089/acm.2020.0144

17. European Monitoring Centre for Drugs and Drug Addiction. EMCDDA Update on the Implications of COVID-19 for People who use Drugs (PWUD) and Drug Service Providers [Internet]. European Monitoring Centre for Drugs and Drug Addiction. 2020[cited 2020 Nov 28];(1):6. Available from: https://www.emcdda.europa.eu/system/files/publications/12879/emcdda-covid-update-1-25.03.2020v2.pdf 
18. McCoy KL. Interaction between Cannabinoid System and Toll-Like Receptors Controls Inflammation. Mediators of inflammation. 2016;5831315. https://doi.org/10.1155/2016/5831315

19. Sexton M, Cudaback E, Abdullah RA, Finnell J, Mischley LK, Rozga M, et al. Cannabis use by individuals with multiple sclerosis: effects on specific immune parameters. Inflammopharmacology. 2014;22(5):295-303. https://doi.org/10.1007/s10787-014-0214-z

20. Hill KP. Cannabinoids and the Coronavirus. Med Cannabis Cannabinoids. 2020;5(2):118-120. https://doi.org/10.1089/can.2020.0035

21. Khodadadi H, Salles ÉL, Jarrahi A, Chibane F, Costigliola V, Yu JC, et al. Cannabidiol Modulates Cytokine Storm in Acute Respiratory Distress Syndrome Induced by Simulated Viral Infection Using Synthetic RNA. Cannabis Cannabinoid Res. 2020;5(3):197-201. https://doi. org/10.1089/can.2020.0043

22. Arksey H, O'Malley L. Scoping studies: Towards a methodological framework. Int J Soc Res Methodol. 2005;8(1):19-32. https://doi. org/10.1080/1364557032000119616

23. Moher D, Liberati A, Tetzlaff J, Altman DG. Preferred Reporting Items for Systematic Reviews and Meta-Analyses: The PRISMA Statement. PLoS Med. 2009;6(7):e1000097. https://doi.org/10.1371/journal.pmed.1000097

24. Tricco AC, Lillie E, Zarin W, O'Brien KK, Colquhoun H, Levac D, et al. PRISMA extension for scoping reviews (PRISMA-ScR): Checklist and explanation. Ann Intern Med. 2018;169(7):467-73. https://doi.org/10.7326/M18-0850

25. Piper C. System for the unified management, assessment, and review of information (SUMARI). J Med Libr Assoc. 2019;107(4):634-636. https://doi.org/10.5195/jmla.2019.790

26. Aromataris E, Munn Z (Eds). JBI Manual for Evidence Synthesis. JBI, 2020. https://doi.org/10.46658/JBIMES-20-01

27. Archie SR, Cucullo L. Cerebrovascular and neurological dysfunction under the threat of COVID-19: Is there a comorbid role for smoking and vaping? Int J Mol Sci. 2020;21(11). https://doi.org/10.3390/ijms21113916

28. Costiniuk CT, Jenabian MA. Acute inflammation and pathogenesis of SARS-CoV-2 infection: Cannabidiol as a potential anti-inflammatory treatment? Cytokine Growth Factor Rev. 2020;53:63-65. https://doi.org/10.1016/j.cytogfr.2020.05.008

29. Hatoum AS, Morrison CL, Winiger EA, Johnson EC, Agrawal A, Bogdan R. Genetic liability to cannabis use disorder and COVID-19 hospitalization. medRxiv. 2020[cited 2021 Jan 03]. https://doi.org/10.1101/2020.11.15.20229971

30. Esposito G, Pesce M, Seguella L, Sanseverino W, Lu J, Corpetti C, et al. The potential of cannabidiol in the COVID-19 pandemic. Br J Pharmacol. 2020;177(21):4967-70. https://doi.org/10.1111/bph.15157

31. Onaivi ES, Sharma V. Cannabis for COVID-19: Can cannabinoids quell the cytokine storm? Future Sci OA. 2020;6(8). https://doi.org/10.2144/ fsoa-2020-0124

32. Wang B, Kovalchuk A, Li D, Ilnytskyy Y, Kovalchuk I, Kovalchuk O. In search of preventative strategies: novel high-CBD cannabis sativa extracts modulate ACE2 expression in COVID-19 gateway tissues. Aging (Albany NY). 2020;12(22):22425. https://doi.org/10.18632/aging.202225

33. Dzobo K, Chiririwa H, Dandara C, Dzobo W. Coronavirus disease-2019 treatment strategies targeting interleukin- 6 signaling and herbal medicine. OMICS. 2020;25(1):13-22. https://doi.org/10.1089/omi.2020.0122

34. Rossi F, Tortora C, Argenziano M, di Paola A, Punzo F. Cannabinoid receptor type 2: a possible target in SARS-CoV-2 (CoV-19) infection? Int J Mol Sci. 2020;21(11). https://doi.org/10.3390/ijms21113809

35. Tahamtan A, Tavakoli-Yaraki M, Salimi V. Opioids/cannabinoids as a potential therapeutic approach in COVID-19 patients. Expert Rev Respir Med. 2020;14(10):965-967. https://doi.org/10.1080/17476348.2020.1787836

36. Land MH, MacNair L, Thomas BF, Peters EN, Bonn-Miller MO. Letter to the editor: possible drug-drug interactions between cannabinoids and candidate COVID-19 drugs. Cannabis Cannabinoid Res. 2020;5(4):340-343. https://doi.org/10.1089/can.2020.0054

37. Usher K, Bhullar N, Jackson D. Life in the pandemic: Social isolation and mental health. J Clin Nurs. 2020;29(15-16):2756-2757. https://doi. org/10.1111/jocn.15290

38. Rojas-Jara C. Quarantine, forced isolation and substance use. J Neuropsychol. 2020;14(1):24-28. https://doi.org/10.7714/CNPS/14.1.203

39. Imtiaz S, Wells S, Rehm J, Hamilton HA, Nigatu YT, Wickens CM, et al. Cannabis use during the COVID-19 pandemic in canada : a repeated cross-sectional study. J Addict Med. 2020[cited 2021 Jan 03];00(00):1-7. https://doi.org/10.1097/ADM.0000000000000798

40. Vanderbruggen N, Matthys F, Van Laere S, Zeeuws D, Santermans L, Van den Ameele S, et al. Self-reported alcohol, tobacco, and cannabis use during covid-19 lockdown measures: results from a web-based survey. Eur Addict Res. 2020;26(6):309-315. https://doi.org/10.1159/000510822

41. Sharma P, Ebbert JO, Rosedahl JK, Philpot LM. Changes in substance use among young adults during a respiratory disease pandemic. SAGE Open Med. 2020;8:205031212096532. https://doi.org/10.1177/2050312120965321

42. Elsohly MA, Mehmedic Z, Foster S, Gon C, Chandra S, Church JC. Changes in cannabis potency over the last 2 decades (1995-2014): Analysis of current data in the United States. Biol Psychiatry. 2016;79(7):613-619. https://doi.org/10.1016/j.biopsych.2016.01.004

43. Tay MZ, Poh CM, Rénia L, MacAry PA, Ng LFP. The trinity of COVID-19: immunity, inflammation and intervention. Nat Rev Immunol. 2020;20(6):363-374. https://doi.org/10.1038/s41577-020-0311-8

44. Pascale A. Psychoactive substance use during the COVID-19 pandemic: toxicological implications from a comprehensive approach and therapeutic challenges. Rev Méd. Urug [Internet]. 2020 [cited 2020 Nov 28];36(3):247-251. Available from: http://www.scielo.edu.uy/pdf/ rmu/v36n3/1688-0390-rmu-36-03-247.pdf 
45. Rezkalla S, Kloner RA. Cardiovascular effects of marijuana. Trends Cardiovasc Med. 2019;29(7):403-407. https://doi.org/10.1016/j. tcm.2018.11.004

46. Pillai P, Joseph JP, Fadzillah NHM, Mahmod M. COVID-19 and Major Organ Thromboembolism: Manifestations in Neurovascular and Cardiovascular Systems. J Stroke Cerebrovasc Dis. 2021;30(1):105427. https://doi.org/10.1016/j.jstrokecerebrovasdis.2020.105427

47. Vidot DC, Islam JY, Marlene Camacho-Rivera, Harrell MB, Rao DR, Chavez JV, Lucas G Ochoa, et al. The COVID-19 cannabis health study: Results from an epidemiologic assessment of adults who use cannabis for medicinal reasons in the United States. J Addict Dis. 2020 [cited 2021 Jan 03];15:1-11. https://doi.org/10.1080/10550887.2020.1811455

48. World Drug Report 2020. Drug use and health consequences [Internet]. 2020 [cited 2021 Jun 28];2: E.20.XI.6. Available from: https://www. unodc.org/unodc/en/data-and-analysis/wdr-2021_booklet-2.html

49. Gonçalves AMS, Ferreira PS, Abreu ÂMM, Pillon SC, Jezus SV. Screening and brief interventions strategies as possibilities for preventive nurses' practice. Rev Eletr Enf. 2011;13(2):355-360. https://doi.org/10.5216/ree.v13i2.10502

50. Anderson P, Kłoda K, Kaner E, Reynolds J, Bendtsen P, Pelgrum-Keurhorst MN, et al. Impact of practice, provider and patient characteristics on delivering screening and brief advice for heavy drinking in primary healthcare: Secondary analyses of data from the ODHIN five-country cluster randomized factorial trial. Eur J Gen Pract. 2017;23(1):241-5. https://doi.org/10.1080/13814788.2017.1374365

51. Pacher P, Steffens S, Haskó G, Schindler TH, Kunos G. Cardiovascular effects of marijuana and synthetic cannabinoids: the good, the bad, and the ugly. Nat Rev Cardiol. 2017;15. https://doi.org/10.1038/nrcardio.2017.130

52. Mamber SW, Krakowka S, Osborn J, Saberski L, Rhodes RG, Dahlberg AE, et al. Can Unconventional Immunomodulatory Agents Help Alleviate COVID-19 Symptoms and Severity? mSphere. 2020;5(3). https://doi.org/10.1128/msphere.00288-20

53. Thibaut F, Hoehe MR. Cannabinoids: For better and for worse. Dialogues Clin Neurosci. 2020;22(3):201-204. https://doi.org/10.31887/ DCNS.2020.22.3/FTHIBAUT 